\title{
Sailing on seas of uncertainties: late style and Puccini's struggle for self-renewal
}

\author{
By AMIR COHEN-SHALEV
}

\begin{abstract}
The popularity of Puccini's melodramatic operas, often derided by "serious" musicologists, has hindered a more rounded evaluation of his attempt at stylistic change. This paper offers a novel perspective of lifespan creative development in order to move the discussion of Puccini beyond the dichotomy of popular versus high-brow culture. Tracing the aspects of gradual stylistic change that began in The Girl from the Golden West (1910) through the three operas of Il Trittico: Il Tabarro, Suor Angelica, and Gianni Schicchi (1918-1919), the paper then focuses on Puccini's last opera, Turandot (1926), as exemplifying a potential turn to a reflexive, philosophical style which is very different from the melodramatic, sentimentalist style generally associated with his work. In order to discuss this change as embodying a turn to late style, the paper identifies major stylistic shifts as well as underlying themes in the work of Puccini. The paper concludes by discussing the case of Puccini as a novel contribution to the discussion of lateness in art, until now reserved to a selected few "old Masters."
\end{abstract}

Keywords: Puccini, late style, life-span development, creativity. 
International Journal of Ageing and Later Life

Beloved and popular, the operas of Giacomo Puccini have at the same time been derided by more "serious" musicologists as the product of a decadent, bourgeois society (Greenwald 1993). No composer communicated more directly with his audience than Puccini; indeed, for many years he has remained a victim of his own reputation, hence the resistance to his music in academic circles (Kerman 2005). In this paper I offer another perspective in order to move the discussion of Puccini beyond this dichotomy of popular versus high-brow culture. The purpose of this paper is to explore the underlying changes in the operas of Puccini from a life-span perspective. For this purpose I describe Puccini's earlier operas, tracing the aspects of gradual change that began with The Girl from the Golden West (1910) and developed through the three one-act operas of Il Trittico: Il Tabarro, Suor Angelica, and Gianni Schicchi (1918-1919). Following this analysis, the paper focuses on Puccini's last opera, Turandot (1926), as exemplifying a potential, if not entirely consummated, turn to a reflexive, philosophical style which is very different from the melodramatic, sentimentalist style generally associated with his work.

\section{Life-Span Perspective and Late Style in the Study of Artistic Creativity}

The study of artistic creativity in late maturity is a relatively recent academic enterprise. The terms altersstill (old age style) or spatstill (late style) appeared in German art history in the first half of the $20^{\text {th }}$ century (Adorno 1949/2002; Brinckmann 1925; Simmel 1922). Nevertheless, until the late 1960's they failed to strike a sympathetic chord with art history in general or with the social sciences (Clark 1972; Rosenthal 1968). These scholars attempted a broad delineation of the art of elderly painters and composers and singled out common stylistic features, such as formal ambiguity, expressive intensity, and lessened attention to detail or to finished surfaces (see Cohen-Shalev 2002). In the US, several behavioral scientists working under the so-called "productivity paradigm" applied statistical procedures to questions pertaining to the resilience, or lack thereof, of creativity during the life span (Lehman 1953; Lindauer 2003; Romaniuk \& Romaniuk 1981; Simonton 1991). Using expert value judgments, these researchers generally found age-decrements to accompany the 
progression of chronological age in the careers of famous artists and literary figures.

These two approaches to life-span creativity - the European approach of "old age style" and the North-American "productivity approach" - are diametrically opposed in outlook and methodology. "Old age style" proponents support a perception of creative ascendance in old age, while the productivity paradigm foresees an age-related decline (see reviews in Cohen-Shalev 2002; Kastenbaum 2000). Evidently, both approaches hinge on opposite and often implicit assumptions concerning human development: the biological model in the case of the productivity approach, and the cultural model of the "old Masters" for old age style proponents (Cohen-Shalev 1989).

Recently there has been a resurgence of interest in the artistic products of late maturity, due, in part, to prolonged longevity, as well as to the branching out of gerontology in the form of life-span developmental paradigm (Baltes 1987). This meta-theoretical paradigm offers a more balanced way of looking at human development, where normative agerelated factors, socio-historical contextual influences and unique life circumstances interact in numerous ways, resulting in a picture of human development as a compound "gain-loss" paradigm. There is a growing number of books and articles concerned with late works of various artists. The most recent additions to the still thin corpus of writing about this issue are the late Edward Said's (2006) On Late Style, Russ McDonald's (2006) Shakespeare's Late Style, Martin Lindauer's (2003) Aging, Creativity and Art: A Positive Perspective on late life Development, Cohen-Shalev's (2002) Both worlds at once: Art in Old age, and Thomas Dormandy's (2000) Old Masters.

Since there is no accepted Grand Theory of aging it will be futile to insist on a single pattern of creative work in old age. However, a general developmental scheme can be suggested based on the analysis and comparison of many artists. In this scheme, the earlier stage of the artistic career usually focuses on the articulation of a core dilemma whose conflicting elements are made to confront each other within a selected genre. Late style, in contrast, represents a transcendence of basic contradictions and a de-sublimation of the core dilemma. Within the new perspective that comes with age, interpretation is idiosyncratic, individual, and at the same time metaphysical and universal. Aging artists often 
refrain from explicating their artistic thinking, showing an antipathy for ordered theory (Cohen-Shalev 2002). There is an ambiguity inherent in the aging situation of simultaneously possessing a sense of self and otherness about oneself. This ambiguity allows for the embracing of literal form and metaphysical content, freedom and discipline, fragments and whole, and ultimately - life and death. Each and every artist, of course, brings his or her own touch and twists to this very general scheme. It is still a matter of speculation whether this belated honesty and "stripping down artifice" is a result of the imminence of death, the privileged freedom from immediate public constraints, a result of a prolonged developmental process, and/or a growing intolerance for any form of artificiality.

Another question is whether old age style can be achieved only by an artistic genius. Most scholars focused on the greatest figures in Western art, such as Shakespeare and Ibsen, as examples of old age style; this raises the possibility that old age style is the exclusive prerogative of the truly great (Lehman 1953). The concept of "late style," on the other hand, is more flexible and wide-ranging. Some late work appears when a writer is near death perhaps at a premature age, and it does not take a Shakespeare to re-evaluate a lifetime of creative endeavor. Many late artworks may not be as epoch-making but may still be inherently different in style from the previous works of the artist. This may well be the case of Puccini.

The perspective used to investigate Puccini's late style can now be more clearly articulated. My point of departure is that the individual versatility of artistic development is underpinned by the unfolding of a life-span developmental process which usually starts with a core dilemma presented in a dramatic and conflictual manner during youth, resolved in maturity, and transcended in old age (Cohen-Shalev 2002). "Old age style" is defined as dealing with unresolved contradictions and offering a distillation of artistic perception and a dispensing with ornament in favor of essentials (Kastenbaum 1992; Said 2006; Woodward 1980, 1991). Because such style is much more difficult to understand and to follow, late works can be subjected to misunderstanding and neglect by the audience and the critics, as is the case with Puccini's last opera, Turandot, which exemplifies the composer's strife to shift from his earlier melodramatic style, offering a more complex and philosophical treatment of the dilemma that pre-occupied most of his works, which can be generally 
defined as the desire for unfulfilled love and its predicaments. In order to show the change in Puccini's style, I describe the beginning of this change in The Girl from the Golden West (1910) and how it developed through the three one-act operas of Il Trittico: Il Tabarro, Suor Angelica, and Gianni Schicchi (1918-1919), until reaching Puccini's last opera, Turandot (1926). The paper further focuses on the late work of Turandot in order to analyze how it captures both the developmental change that drove Puccini's creativity and his inability to move beyond his artistic conventions. This arrested change will be discussed as exemplifying the difference between a full-fledged "old age style" and the more open-ended "late style" of Turandot. Before proceeding to the operas, the following section provides an overview of Puccini's late artistic period in historical perspective.

\section{Puccini in Historical Context}

I focus here on the late period of the famous Italian opera composer Giacomo Puccini (1858-1924), whose achievements - while a sure entry in every important compilation of opera composers - fall short of fellow composers such as Monteverdi, Verdi, Wagner, or Janacek. These four artists earned their right of entry to the pantheon of late stylists owing to works produced at the end of a relatively long life. Wagner produced Parsifal at 69, Verdi with Othello and Falstaff at age 74 and 80 respectively, and Monteverdi with The Coronation of Poppea, at 75. Richard Strauss, Puccini's contemporary, also appears in old age style lists, but mainly due to his orchestral works and one song cycle, with only one opera, Intermezzo, composed at 75.

Puccini can be placed in a number of significant contexts (Greenwald 1993). He is widely regarded as the inheritor of the mantle of Verdi, the last composer of the so-called "Great Tradition" in Italian opera. Furthermore, because Puccini kept abreast of compositional techniques of his time, he may be studied quite validly as a $20^{\text {th }}$ century composer. While Puccini died at 66, his late works in general, and particularly Turandot - the opera he was busy with for the last four years of his lifemerit a serious re-consideration as a particular specimen of lateness. Such an analysis will enrich and open up the discussion of lateness in art, until now reserved to a selected few among the greatest of artists. Creators in 
International Journal of Ageing and Later Life

more popular media, such as opera and film, have thus far remained largely outside discussions of old age style. Puccini was a consummate opera composer, but, even to his admirers, he was not regarded as a musical genius.

The opera entered, in the $19^{\text {th }}$ century, the cultural and spiritual vacuum left by the demise of tragedy (Steiner 1961), filling it with middle-class popular entertainment fortified by rising nationalistic sentiments. Opera originated in Italy, at the first half of the $17^{\text {th }}$ century, with the musical and dramatic innovations of Monteverdi. In terms of plots, these early ventures drew most directly from Romano-Greek antiquity, and grew in themes and scope during the next two centuries, partly with the purpose of accommodating themes closer and dearer to the newly formed bourgeois audiences. In the $19^{\text {th }}$ century, first with Rossini and Donizetti and then with Verdi, the opera turned into an artistic form of expression that catered to the growing ranks of the middle-class. Verdi's very own "tragic melodrama" which he almost single-handedly developed starting with Rigoletto in 1851, proved a perfect vehicle for middle and late $19^{\text {th }}$ century Romantic spirit. Toward the end of the century, perhaps in anticipation of political instability to come, the Great Tradition of Italian opera was coming to an end. For all its universal appeal, Verdi's music was inextricably bound with the Italian political movement toward independence (the Risorgimento). While Verdi took a 16-year break from opera, following the success of Aida, a young generation of Italian opera composers was already in pursuit of a new operatic idiom. As Italy was already independent, the flames of nationalistic sentiment went down; these youngsters, among them Mascagni, Leoncavallo, Giordano, Boito and Pizzzeti, readily absorbed cultural influences from the continent, first and foremost the naturalistic drama of the north. Late $19^{\text {th }}$ and early $20^{\text {th }}$ centuries saw the rise to popularity of a new genre, the "verismo" - the operatic equivalent of the realistic theater: heroes and heroines of the middle and lower ranks of society, stories of earthly passions, and a "flat" declamatory musical expressions (often pushed to extreme), which preferred dramatic content to traditional melodic values (Ashbrook \& Powers 1991). There was more raw passion than elegant discipline in the verismo style, which is perhaps why it was short-lived. 
Born in 1858, at the height of Romanticism in musical life, Puccini grew up at a time when Italian opera, dominated by Giuseppe Verdi, was looking for a new dramatic idiom - the verismo - resulting in a hybrid of German Wagnerism and Ibsen-like naturalism. Puccini is also an important figure of the verismo movement in the Italian opera. For him, melodrama was more than a formal genre, a structural framework or a theatrical device, to be manipulated with flexibility and care. He became identified with a melodramatic approach. When he felt his progressing years demanded something else he was already "imprisoned" in the narrative and psychological constraints of a particular musico-dramatic genre that he had shaped for himself and for his audience in almost four decades of his career. Like a mask that has grown too close to the skin, it could probably be removed only at the price of tearing the skin itself.

\section{The Seeds of Transformation: From The Girl of the Golden West (1910) to Il Trittico (1918-19)}

One does not choose one's subject, wrote Flaubert; one is chosen by it. This maxim explains why opera composers rely on someone else's story but also spend years looking for a suitable one. Throughout most of his career, Puccini has been looking for stories of a very specific theme - sentimental and melodramatic. This recurring theme is articulated by a marginal figure, a street vendor in The Cloak: "Chi ha vissuto per amore per amore si morri" (she who lives for love, dies for love.) A Puccini heroine is a character who is feminine, frail, of humble origin and somewhat doubtful in moral virtue, seeking true and unbound love. Her happiness in finding it is short-lived, and she is crushed by cruel fate: torture, broken heart, or suicide. Manon (Manon Lescaut), Mimi (La Boheme), Tosca, Cio-Cio San (Madame Butterfly), Minnie (The Girl From the Golden West), Giorgetta (Il Tabarro), Angelica (Suor Angelica) and Liu (Turandot) - all these female characters of Puccini live for love in the first act and die for it in the third. Puccini was so fond of torture scenes that he was accused of misogynic sadism (Carner 1964).

The emotional range of these female characters was therefore rather narrow, a fact Puccini himself was keenly aware of. His letters indicate a constant search for a new class of subjects, that Weaver (1977) calls 
International Journal of Ageing and Later Life

"un-Puccinian heroines," like the unusual Minnie in the Girl of the Golden West, as tender as his previous heroines, but also tough and capable of "masculine" feats. At 52, with his three midlife successes behind, The Girl of the Golden West (1910) was a first serious attempt to break away from the convenient sentimentalist formula for a different breed of female protagonists. While not always satisfactory in its musical and dramatic treatment (see Carner 1964: 279) this work was a landmark in Puccini's creative evolution, where musical characterization becomes as, if not more, important than the sheer beauty of melody, and musical numbers are integrated into the dramatic texture.

Abandoning lyricism for its own sake and moving away from soppy sentimentalism and coarse verismo naturalism proved an awesome task for Puccini. Apparently, The Girl of the Golden West was worthy in intention, less so in execution. Eight years later Puccini completed three one-act operas, known as Il Trittico (1918). By confining the scope he was able to break the challenge into smaller, more manageable parts, and that seems to have worked. Carner's (1964) description of the score of Il Tabarro (The Cloak) takes us into the territory of old age style. In it, Puccini

achieves a degree of compassion and terseness as well as a close correlation between means and end...the structure of melodies is more balanced and symmetrical [...] there is an organic coherence and a marked preference for using a few themes in their entirety instead of a multiplicity of brief figures (Carner 1964: 464).

Carner also notes a shift away from complex chord clusters toward simpler harmonies, greater simplicity and directness in the scoring, and orchestral lines drawn with new sharpness, and altogether, a style of chamber music despite the employment of a large orchestra.

That last description brings to mind Puccini's contemporary composer, Richard Strauss, whose last composition, the Four Last Songs, does indeed sound strangely chamber-like, even airy, though the score is written for an augmented symphony orchestra. The textures are dense, created by extensive use of instrumental doubling to suggest autumnal glow. While Strauss is a recognized old age stylist, and the piece in question was his last (written at the age of 84), Puccini's affinity with creative lateness had so far gone unnoticed. Still, it was a conversion of considerable importance, as Puccini relied outwardly on the dramatic conventions of 
the verismo style only to shed them subtly in favor of a diametrically opposite dramatic restraint and emotionally realistic characterization.

Simplicity, economy and profoundness are no doubt the hallmarks of good art in general - but they were not characteristic of Puccini's art until fairly late in life. Because of his temperament and the expectation of opera goers, Puccini did not combine passion and restraint successfully until the end of his life. The nervous, even hysterical fluctuations between extremes of emotional expressions gave way to a dynamic evenness throughout, a quality that obviously contributes to the sense of organic coherence. This unifying influence is felt first and foremost in the orchestral score. Il Tabarro's melodic material consists of two recurrent leitmotifs, the reduction and repetition musically enhance the dramatic unity and at the same time establish suggestive tonal ambiguity. The opening river motive, for example, "[...] invades the stage like an evil mist through which the characters move" (Carner 1964: 424).

Il Tabarro presents yet another aspect of Puccini's essential transformation, which concerns rhetorical characterization. In the triangle of Michele, the middle-aged Barger, his younger wife Giorgetta and her lover Luigi, it is the older man who is dramatically the most well-rounded and fully developed. His soliloquy reflecting on his wretched life and contemplating revenge on his younger contender over his wife's heart is "a piece almost to worth to rank with some of Verdi's baritone or bass arias" (Carner 1964: 424). It is a musically convincing and psychologically believable portrayal of a desperate, tortured man whose debased existence drives him into paroxysm of murderous jealousy. It is Puccini's first fully fledged, mature male protagonist. The preceding ones were either effeminate, puppetlovers tenor roles or semi-pathological villainous sadists - Scarpia in Tosca, Rance in The Girl of the Golden West - or sympathetic but passive observers: the consul in Madame Butterfly, and Marcello in La Boheme.

Il Tabarro also exemplifies a change that was influenced by Debussy, Puccini's contemporary French composer. On the face of it, the introverted, introspective music of Debussy was the complete opposite of Puccini's melodramatic operas. Nevertheless, while working on Il Tabarro Puccini looked to Debussy for inspiration. Unfortunately, Debussy died while Puccini was working on Il Tabarro. Puccini's eulogy for Debussy is helpful in understanding his own search: 
International Journal of Ageing and Later Life

Today I hear people speaking as if [his music] were a system to follow or not to follow [...] Doubts assailed this great artist in his later years. Even to the composer himself they appeared to represent a restricted field of experiment [...] I know how much he attempted in vain to escape from this field. I was anxiously awaiting to see how Debussy himself proposed to revolt against Debussyism (Budden 2002: 327).

In this letter, coinciding with Il Tabarro's premiere, it appears that Puccini identified with his colleague's struggle to free himself from his own stylistic reputation.

One year after Il Tabarro, in 1919, was the premiere of Puccini's second one-act opera, Suor Angelica: the story of a young woman, noble by birth who retires to a convent after having given birth out of wedlock. This fact is revealed to the audience half way through the story upon an unexpected visit of the woman's haughty aunt, informing her of the death of her child. In her agony the bereaved mother swallows poison. Realizing the terrible sin she has just committed she poignantly prays to the virgin mother for forgiveness. Overcome by delirious ecstasy she sees a vision of the Virgin leading the child into her arms.

While the dramatic content promises a second Butterfly, Suor Angelica is Puccini's most un-dramatic, even static work bereft of theatrical fireworks. The insistence on sameness of tone and on thin melodic material seems to suggest an experiment in un-Puccinian musical drama, the making of a genuine dramatic feeling with minimal recourse to action and narrative contrivance. The composer persists honorably, until cracking under duress. The final scene, where the heroine goes through a mystical metamorphosis, is the weakest moment in the drama, since she cannot but pronounce an all-too conventional jarring note. It appears that the relief of a desperate female soul was beyond Puccini's creative powers at that point in his artistic career, and he retreats to the very mechanisms he had desperately tried to avoid. Like his heroine's, Puccini's attempted transformation remains artistically unfulfilled.

Still, Suor Angelica continues the path paved by its immediate predecessor: The chamber quality, ensemble rather than an amalgamation of virtuoso soloists, a slim but expressive accompaniment, a focus on a complexity (as opposed to oversimplification) of emotions and a general, inward restraint that sets it apart in the composer's operatic corpus. Further setting it apart is the all-female cast, standing out when compared 
to the often abusive treatment of the female character in earlier works, a combination of angelic innocence and seductiveness. The multiplicity of female voices creates an overall feminine presence of unprecedented weight and depth. The juxtaposition of high and low women's voices creates a vertical space, which, musically as well as psychologically, affects a standstill perception of time, which was new to Puccini.

\section{Absolution through Comedy: Gianni Schicchi}

The third part of the one-act triptych, Gianni Schicchi, was already unique in being Puccini's first comedy. Puccini, who for many years had entertained the idea of writing a comic opera, found the subject in Dante's Divine Comedy. Gianni Schicchi, a $13^{\text {th }}$ century Florentine schemer is urged by the Donati family to prevent the execution of the just deceased Buoso Donati's will, bequeathing all his wealth to the Church. Impersonating the dying man, Schicchi dictates a will in which he orders Buoso's property to himself. Having driven the outraged relatives from what is now his lawful property he notices his daughter, obliviously in love with Buoso's nephew. His closing (spoken) monologue is directed from the stage to the audience:

\footnotetext{
Tell me ladies and gentlemen, could you imagine a better use for Buoso's money? For this trick I have played, these people have sent my soul to Hades. Well, Amen! With all deference to the great Dante, if you have enjoyed yourselves tonight, I hope you will applaud the verdict - not guilty (gracefully bows). From the libretto.
}

These closing lines may be interpreted as a clever apology, a camouflaged reflection on a career that, by then, spanned almost 35 years, a career which had often been subjected to ferocious criticism. Puccini pleads guilty to the accusations and at the same time elegantly absolves himself. The lighter vein of comedy enables the replacement of bitter selfdepreciation (a response Puccini had been known to indulge in) with self-absolution.

Puccini was extremely fond of the character of Gianni Schicchi. The similarities are suggestive. Both were deeply rooted in their native Tuscany; both were artisans, making use of theatrical devices skillfully for the purpose of making profit; both have been accused of opportunism, and the composer seemed to share Schicchi's delight in sheer wickedness. 
International Journal of Ageing and Later Life

Acknowledging his debt to Dante, Puccini feels entitled for a humble claim to fame, added to a sense of irony: the composer who failed to redeem his dolorous heroines through love or faith, is redeeming himself through laughter. Moreover, it appears that the seeds of reflexivity and irony in Schicchi paved the way for Puccini's real confrontation with the stylistic chains of melodrama - Turandot.

\section{Turandot: Confronting the chains of melodrama}

Turandot is performed regularly, and has been recorded a number of times, but compared to Puccini's earlier operas - La Boheme, Tosca and Madame Butterfly - it is less popular, less recorded and all in all less liked by the audience. Whatever Puccini tried to do differently in Turandot, he generally failed with the public. Turandot is based on Carlo Gozzi's $18^{\text {th }}$ century parable, a tale of a man-hating Chinese princess, whose hand will be given to the suitor who will crack her three riddles - mythical devices shared by various cultures. The game is played for high stakes, the prize being the princess' hand in matrimony. The stake is the head of the hapless suitor. George Marek (1951), Puccini's biographer, called Turandot "the quiz opera par excellence" not by virtue of the plot, but because outside the opera itself, in the history of its creation, there was a further enigma: the fact that it took four years to write.

When he started working on Turandot, in 1920, Puccini was 62. To attribute the slow progress to age, health or both, is unjustified, considering his overall level of activity at the time. He was, if anything, busier than ever before. Based on the letters sent to his librettist during the four years of Turandot's difficult conception it seems the composer had an intense struggle with his chosen subject, something the prolific musician never encountered in nearly four decades of composing. Always demanding a great deal of his librettists he now turned into a restless despot, regarding every line with hypercritical eye, changing his mind innumerable times, never satisfied with the result.

Two scenes caused special difficulty: the first scene of the second act (the scene of the three courtiers), and the final duet between the princess and prince Calaf. "It is because of Turandot that I feel like a lost soul [...] that second act! I cannot find a way out," wrote Puccini (Budden 2002: 427). 
This scene is sung entirely by three masked figures, in the tradition of the commedia dell'arte. The long scene is divided into two parts, sharply contrasting in mood, the first a jovial conversation on the latest suitor, indulging in a rhythmic singsong. The second part is a melancholy rumination on the fate of China under the tyranny of Turandot, where heads fall like apples and worthy men try in vain for the hand of the ice princess. The singers are weary of the horror and dream nostalgically of recapturing lost tranquility.

Another Puccini biographer suspected that the librettists' delay in sending the composer more material had been caused by their lack of faith in his ability to handle it successfully (Greefield 1980.) He had never before handled shifting perspectives and ironic subtleties. To bring off these mercurial and ambivalent characteristics seemed out of character with Puccini's habitual emotional simplicity and melodramatic univalence. Now he had to deal with a divided style - to juggle the comic and the melancholic and still maintain dramatic unity and coherence. As Budden (2002) commented, Puccini failed in crossing the opera's chief hurdle, namely the transformation of its heroine by the power of love. Every decision that he took during the opera's gestation rendered his task more difficult; "in his hands [Turandot] became progressively more inhuman" (Budden 2002: 472). She remains iron-clad up to the moment of the kiss, while Calaf's love also amounts to mere physical obsession.

Puccini did eventually solve the difficulty with the above scene, and quite satisfactorily. But then he was faced with a still greater task, the third act duet. This apotheosis duet was meant to be the culmination of a continual struggle between two dominant personalities, Princess Turandot and Prince Calaf, where the icy Princess melts away. "It must be a grand duet, the two beings, almost not of the world, come amongst humans through love, and in the end this love should pervade the whole stage" (a letter from Puccini to Adami, November 16, 1924, cited in Ashbrook \& Powers 1991: 88). This majestic confrontation proved an insurmountable creative obstacle. Two months before his death, already ill with throat cancer, while Puccini was negotiating a date for its premiere, the scene was still in sketch form, posthumously completed by his pupil, Franco Alfano.

The completed scene has since been a subject for debate, and is unanimously considered less than satisfactory, not just because of Alfano's 
International Journal of Ageing and Later Life

rather conscientious effort. Puccini's letters paint a picture of creative impasse. He had been paralyzed by the task facing him: "I am a little doubtful because it is the type of opera that terrifies me. I should have preferred something of a different kind" he wrote in December 1921 (cited in Ashbrook \& Powers 1991: 76.) Two and a half years later, in May 1924, he was desperate: "Turandot lies here unfinished [...] I have no desire to work." Puccini's correspondence during the painfully long gestation of Turandot reveals his desperate attempt to move beyond the previous schemes of his art. He instructs Simoni, the librettist, to "exalt Turandot's amorous passions, which she had smothered for so long beneath the ashes of her great pride." (Budden 2002: 426.) In Turandot, Puccini must have found a promise and a prospect for reconciling two warring images of the female psyche: the fair sinner consumed by love, and the cruel chimera, motivated by sexual repression. These two contradicting images had already been juxtaposed in Suor Angelica, with Angelica and the aunt as their counterparts. In Turandot, these two aspects had to be converged in a single role. Apparently there was nothing wrong or regressive in Puccini's artistic powers when he was working on Turandot. However, Turandot called for a different arrangement of the impulsive (that is, youthful) melodramatic elements, and for a philosophical - perhaps ironic distance.

Puccini arguably took protective measures in case he did not succeed in confronting the complexities of Turandot. The choice of ancient China as a backdrop for the plot provided one safeguard, affording ample opportunity for scenic, luscious, and sensuous musical effects. Another safeguard concerned the puzzling introduction of the faithful slave girl Liu, a character that is entirely Puccini's invention, not present in Gozzi's play. In November 1922, already two years into the work, he decided Liu had to die, the reason being that her death could help soften the heart of the princess. For Liu's death scene he wrote his most inspired music, so much so as to overshadow the following grand duet, where the statement of the triumph of love was to be made. It was eventually Liu - and not Turandot - who captured the audience's fancy, contrary to the conscious intentions of her creator.

My argument concerning the lateness of Turandot's can be complemented by other interpretations. It is widely accepted by Puccini's scholars that 
Turandot was not a wholesome attempt on his part to liberate himself from old models. As Wilson (2005: 435) summarizes, "Turandot is an opera that plays out a discursive dialogue with itself, in which Puccini attempts to reassess his artistic oeuvre past and present." Some sections of the opera are therefore conventional, while other sections of the score, notably Turandot's music, were characteristic of the more modern style that Puccini had been developing since the 1910s. These disjunctures in the musical score can be seen to represent the underlying conflicts of selfrenewal from a perspective of life-span artistic development. However, these differences can also be viewed as stemming from external influences, such as Puccini's response to a shifting artistic climate, which might have pointed the way to even more adventurous experimentation, had death not intervened. Evidently, there is no one parsimonious explanation in this matter. After all, internal artistic development is always intertwined with external influences. I thus concur with Wilson's (2005: 436) interpretation that "Turandot, like Verdi's Falstaff before it, illustrates the fact that the new relationship between artist, art work, and audience that modernism demanded was unworkable within the traditional paradigms of Italian opera. The critics' puzzled reaction to both works raised questions about the extent to which artistic renewal was in fact any longer possible within the Italian operatic tradition." Nevertheless, it was that very Italian operatic tradition in which Puccini felt at home and which gained him his reputation.

\section{Conclusion}

A common pattern of artistic development among dramatists involves a movement in late life away from tragedy, or other forms of tragic drama, to metaphysical fantasy. Shakespeare's four last plays, from Cymbeline to The Tempest, Ibsen's late quartet, from Little Eyolf to When We Dead Awake, and Verdi's Falstaff, a masterpiece of late maturity - are cases in point (see McDonald 2006). Having cultivated a tragic form of dramatic expression in midlife, these writers and musical dramatists seem to have had a change of creative style, resulting in more open, flexible and less formal expressions in their old age. 
International Journal of Ageing and Later Life

For the most part of his career Puccini had been engaged with melodrama. This is not to belittle the power or value of melodrama, an essential component for dramatic expression. Erik Bentley (1967), for example, argued for the indispensable role of melodrama in theater. Still, while for theatrical performance melodrama is a pillar, for Puccini it was the whole edifice. Unlike his predecessor, Verdi, genuine tragic feeling was probably beyond Puccini's personal and artistic sensibilities. As the works analyzed here showed, the late style perspective finds corroboration in the artistic change with which Puccini experimented as he tried to move, in his late period, away from the earlier melodramas that made him famous and popular. With The Girl from the Golden West (1910), love is eventually fulfilled (the first time in Puccini's work), yet after a long and winding road. The desire for unfulfilled love and its predicaments continues to occupy Puccini in Il Tabarro (1918), where the aging protagonist contemplates revenge on his younger contender over his wife's heart, and then in Suor Angelica (1919), where the young protagonist retires to a convent after having given birth out of wedlock. In Gianni Schicchi (1919), being a comedy, love wins out more easily and without the melodramatic twists. In Turandot (1926), the struggle for the princess' love also drives the plot. However, trying to shift from melodrama to a more philosophical and transcendent mode of contemplation, Puccini was only half successful. The difficulty of fully realizing the shift to late style, as well as the desire to do so, are both exemplified in Puccini's unresolved struggle with the composition of Turandot. This late work therefore captures the subtle and complex interplay of an authentic, life-span developmental urge, as well as the pressures for continuity and stagnation.

The dramatic, psychological and musical changes that Puccini experimented with in Il Trittico proved unsatisfactory as a preparation for a full transformation to "old age style." Moving directly from verismo melodrama to the philosophical fantasy of Turandot proved too broad a leap. Perhaps it was his commitment to place and tradition that prevented him from crossing over to the territory of lateness, which - as Said (2006) pointed out - represents a kind of mental exile. Due to Puccini's premature death in the age of 66, we will never know for sure whether he would have been able to complete the change to old age style. In terms of his public relations and the public image of the genre in which he 
worked, Puccini's reputation as a popular entertainer certainly stood in the way of his desire to reach the status of a serious auteur (Becker 1982; Kapsis 1989). A careful analysis of his late operas and of his correspondence during his work on them shows that Puccini wanted to move away from those old operatic "war horses" of melodrama, and to find creative equivalences for his own coming of age. The works of his last years, from $I l$ Tabaro in 1918 to Turandot, left incomplete upon his death in 1924, are the products of a will to say something different, more worthwhile perhaps, than the earlier hits. As Budden (2002: 477-478) similarly argues,

\footnotetext{
From his student days Puccini had determined to cut his own way through the various influences that impinged on Italian opera during its years of uncertainty, forging a language that is instantly recognizable $[. .$.$] permitting the assimilation of contem-$ porary elements into a sturdy, developing organism [...] At the same time [the] popular trilogy [...] sits comfortably within the tradition of the 'giovane scuola' which, as he himself pointed out, Puccini had helped to found and which he eventually outgrew.
}

The late style of Puccini, therefore, opens up a window to the stylistic confrontation of tradition and innovation in late life. Late style is characterized by the desire for self-renewal alongside a commitment to earlier stylistic forms. As Puccini's case demonstrates, this commitment inhibits the developmental push by clinging to midlife conformity, generating a difficult, torturous interplay between advance and regression.

\section{Corresponding Author}

Amir Cohen-Shalev, Department of Gerontology, University of Haifa, IL-31999 Haifa, Israel 31999. Email: cohenshalev@gmail.com

\section{References}

Adorno, T. W. (1949/2002). Essays in Music. Introduction and commentry by Leppert, R. Berkeley, CA: University of California Press.

Ashbrook, W. \& Powers, H. (1991). Puccini's Turandot, the End of the Great Tradition. Princeton, NJ: Princeton University Press.

Baltes, P. B. (1987). Theoretical propositions of life span developmental psychology. Developmental Psychology 23(5): 611-626. 
International Journal of Ageing and Later Life

Becker, H. (1982). Art Worlds. Berkeley, CA: University of California Press. Bentley, E. (1967). The Life of the Drama. New York: Atheneum.

Brinckmann, A. E. (1925). Spatwerke Grosser Meisters. In G. Rosenthal (1968) (ed.) From El Greco to Pollock. Baltimore, MD: Baltimore Museum of Art.

Budden (2002). Puccini: His Life and Works. Oxford: Oxford University Press.

Carner, M. (1964). Puccini: A Critical Biography. New York: Alfred A. Knopf.

Clark, K. (1972). The Artist Growing Old. The Rede Lecture, 1970. Cambridge: Cambridge University Press.

Cohen-Shalev, A. (1989). Old age style: Developmental changes in creative productivity from a life span perspective. Journal of Aging Studies 1(3): 21-37.

Cohen-Shalev, A. (2002). Both Worlds at Once: Art in Old Age. Durham, NC: University Press of America.

Dormandy, T. (2000). Old Masters: Great Artists in Old Age. London: Hambledon and London.

Greefield, H. (1980). Puccini: A Biography. New York: Robert Hale Publishing.

Greenwald, H. (1993). Recent Puccini Research. Acta Musicologica 65(1): 23-50.

Kapsis, R. (1989). Reputation building and the social art world: The case of Alfred Hitchcock. The Sociological Quarterly 30(1): 15-35.

Kastenbaum, R. (1992). The Creative Process: A life span Approach. In T. R. Cole, D. Van Tassel \& R. Kastenbaum (eds.) Handbook of the Humanities and Aging (pp. 285-306). New York: Springer Publishing Company.

Kastenbaum, R. (2000). Creativity and the Arts. In T. R. Cole, R. Kastenbaum \& R. E. Ray (eds.) Handbook of the Humanities and Aging (pp. 381-401). New York: Springer Publishing Company.

Kerman, J. (2005). Opera as Drama. Berkeley, CA: University of California Press.

Lehman, H. (1953). Age and Achievement. Princeton, NJ: Princeton University Press. 
Lindauer, M. S. (2003). Aging, Creativity and Art: A Positive Perspective on Life Span Development. New York: Springer.

Marek, G. (1951). Puccini: A Biography. New York: Simon and Schuster.

McDonald, R. (2006). Shakespeare's Late Style. Cambridge: Cambridge University press.

Romaniuk, J. G. \& Romaniuk, M. (1981). Creativity across the Life Span: A Measurement Perspective. Human Development 24(6): 366-381.

Rosenthal, G. (1968). From El Greco to Pollock. Batimore, MD: Baltimore Museum of Art.

Said, E. W. (2006). On Late Style: Music and Literature against the Grain. New York: Pantheon Books.

Simmel, G. (1922). Das Abendmahl Leonardo da Vincis', in Zur Philosophie der Kunst. [The Last Supper by Leonardo da Vinci, in On the Philosophy of Art] (pp. 55-60), Potsdam, Germany.

Simonton, D. K. (1991). Creative productivity through the adult years. Generations Spring, 13-16.

Steiner, G. (1961). The Death of Tragedy. New York: Hill and Wang.

Weaver, W. (1977). Puccini: The Man and His Music. New York: Dutton, Metropolitan Opera Guild composer Series.

Wilson, A. (2005). Modernism and the machine woman in Puccini's 'Turandot'. Music \& Letters 86(3): 432-453.

Woodward, K. (1980). At Last, the Real Distinguished Thing: The Late poetry of Eliot, Pound, Stevens and Williams. Columbus, OH: Ohio State University Press.

Woodward, K. (1991). Aging and Its Discontents. Bloomington, IN: Indiana University Press. 